\title{
The Performance of Opposition Parties in Competitive Authoritarian Regimes: Three Case Studies from the Western Balkans
}

\author{
Claudia Laštro $^{1} \cdot$ Florian Bieber $^{1}$
}

Accepted: 5 February 2021 / Published online: 16 March 2021

(C) The Author(s) 2021

\begin{abstract}
This article investigates opposition to the competitive authoritarian regimes in Montenegro (1997-2020), North Macedonia (2006-2017), and Serbia (2012-). In each of the three countries, opposition parties face or have faced the challenge of competing on an electoral playing field that is structurally skewed in favour of the incumbent. The articles explore the question in which circumstances opposition parties have been able to contest the dominant parties. In doing so, it focuses on three dimensions, namely the relationship between spatial party competition, different levels of opposition cohesion or fragmentation, as well as extra-institutional strategies of contestation. The country comparison illustrates that party systems with crosscutting cleavages tend to produce divided patterns of contestation (Montenegro and Serbia), whereas reinforcing cleavages facilitate the coordination among different types of opposition actors (North Macedonia). Finally, large protests, rather than boycotts, prior to elections have been important factors in facilitating opposition cohesion and signalling broad support (Montenegro and North Macedonia).
\end{abstract}

Keywords Competitive authoritarianism $\cdot$ Montenegro $\cdot$ North Macedonia · Opposition · Serbia $\cdot$ Western Balkans

Symposium 'Political Oppositions beyond Liberal Democracy' Article 'The Performance of Opposition Parties in Competitive Authoritarian Regimes. Three Case Studies from the Western Balkans'.

Florian Bieber

florian.bieber@uni-graz.at

Claudia Laštro

claudia.lastro@edu.uni-graz.at

1 Centre for Southeast European Studies, University of Graz, Schubertstraße 21/1, 8010 Graz, Austria 


\section{Introduction}

Over the past two decades, political scientists have subsumed the regimes of the Western Balkans under the broader agenda of democratisation and Europeanisation studies (for a related discussion see, for example, Bieber 2014). The steady moderation of party programmes since the early 2000s, the adoption of formally democratic procedures, and the nominal commitment to Europeanisation across party families fuelled scholarly confidence that the Western Balkans states would eventually arrive at the same stage of democratic development as their Central and Eastern European counterparts. For most of the Western Balkans countries, this optimism has proven to be premature by the substantial decline of democracy and the increase of authoritarian practices during the 2010 s. Some states have even seemingly embarked on a trajectory where autocratic strongmen successfully concentrated power within structurally weak institutions, whereas in other cases, the fragility of democratic institutions has become visible (Bieber 2020; Dolenec 2013). Thirty years after the end of socialism, many countries of the Western Balkans remain stuck in a grey zone of regimes, that contain democratic as well as authoritarian features (Bieber 2018; Levitsky and Way 2020).

The recent interest in what Schedler (2006) termed 'electoral authoritarianism' or what Levitsky and Way (2002) named 'competitive authoritarianism' has given rise to a wealth of studies confronting the puzzle of autocrats' resilience in spite of competitive, albeit restricted, multiparty elections (see, for example, Way 2012; Wright and Escribà-Folch 2011). In general, opposition mobilisation represents one of the most serious threats to autocratic survival, especially if the opposition manages to contest as a unified force (Gandhi and Ong 2019; Bunce and Wolchik 2011). It is also well established that autocrats employ an entire 'menu of manipulation' (Schedler 2002) aimed at reducing the opposition's visibility, raising costs of contestation, and restraining the access to necessary resources (see, for example, Bhasin and Gandhi 2013; LaPorte 2015; Magaloni 2006). But opposition parties may also face a number of unintended challenges, "challenges that exist quite apart from whatever the incumbent is doing to deter unity" (Gandhi \& Buckles, 2016).

This article examines the opposition in Serbia (since 2012), Montenegro (1990/7-2020), ${ }^{1}$ and North Macedonia (2006-2017), three countries in which competitive authoritarianism was most entrenched during the past decade in the Western Balkans. In the case of North Macedonia, authoritarian rule ended in 2017 following revelations of abuse of office in leaked wiretaps. In Montenegro, the dominant ruling party lost elections in August 2020 in a surprise defeat after 30 years in office. Serbia, unlike the other two cases, continues to be dominated by the Serbian Progressive Party (SNS) since 2012. The article seeks to examine the reasons why the

\footnotetext{
1 Montenegro has been a competitive authoritarian regime since the introduction of a multiparty system in 1990. The period between 1990 and 1997 was marked higher levels of repression, a more pronounced dominance of the ruling party and rejection of the European Union. Following the split of the ruling Democratic Party of Socialists in 1997 between a pro-Western and a pro-Milošević faction, the current system emerged.
} 
opposition has managed to defeat the incumbent in North Macedonia and in Montenegro, whereas in Serbia the dominance of the ruling party remains unchallenged. We argue that apart from individual events that have altered the opposition's opportunity structure - such as the revelation of large-scale abuse of office (North Macedonia) or a controversial law (Montenegro) — the capacity of the opposition to effectively challenge incumbents depends on the nature of cleavages that underpin social and political divisions, as well as on the nature of the opposition parties and their mobilisation strategies.

The dominant parties in all three cases (usually governing in a coalition) dismantled (or stifled) independent institutions, curtailed media freedom, and monopolised state resources. The resulting insider-outsider divide has subjected competition to a zero-sum game whereby opposition parties are forced to adapt their responses to the character of the regime (see also, Helms 2020). The asymmetric resources and patronage in authoritarian regimes require resource-poor opposition parties to provide voters with programmatic reasons for choosing them (Greene 2010, 758). Moreover, challengers need to confront the central dilemma whether to compete within institutions that are inherently flawed or to opt out and embark on extra-institutional means. Among the country cases in this study, opposition parties widely vary in type, cohesion, strategic choices, and not least, their success. Thus, our comparative analysis seeks to contribute to a better understanding of the conditions and strategies of party competition in competitive authoritarian regimes.

In the sections below, we will first outline the key features of the three competitive authoritarian regimes and the dimensions of spatial party competition in each country, followed by a discussion of the coalition building strategies of opposition parties and the key extra-institutional strategies they employ. The focus on these three dimensions is due to their centrality in opposition parties challenging incumbents in competitive authoritarian regimes.

\section{Case Selection}

In the 1990s, competitive authoritarian regimes ruled several countries of the Western Balkans that retained power with a combination of patronage, nationalism, and repression behind the façade of nominally democratic institutions. These systems were the product of the end of socialism and the dynamics of state dissolution. Their fall around 2000 was much aided by the unification of various opposition actors that, under the banner of democratisation and European integration, represented credible alternatives to the autocratic ruling parties (Vachudova 2005; Bunce and Wolchik 2011). Despite a short period of government alternations, democratic procedures failed to consolidate. Instead, the countries of the region have been persistently plagued by a steady decline in press freedom, the erosion of independent institutions, and the return to a personalised and network-based style of leadership (Kmezić and Bieber 2015; Vachudova 2019). Although all states of the Western Balkans feature considerably weak institutional safeguards, only Serbia, Montenegro, and North Macedonia witnessed the return of dominant parties — or in the case of Montenegro, the thirty-year monopoly of one dominant party with different periods 
of liberalisation and more authoritarian control. The decisive variation across the region, therefore, lies less in the weakness of democratic institutions, but crucially in the autocratic parties' ability to take advantage of deficiencies against the backdrop of a diffuse opposition (Bieber 2018, 338; Keil 2018).

In accordance with the thematic focus of this symposium, we will concentrate on those countries, where dominant parties managed to regain or retain control during the past decades. The peculiarity of today's competitive authoritarian regimes is their proximity to the European Union. In all three countries, autocratic governments have been nominally committed to European integration assigning them a gatekeeper position for the establishment and maintenance of structural ties with the EU. In contrast to the opposition movements at the turn of the millennium (Vachudova 2005), linkage to the EU is a resource not easily available to today's opposition parties.

\section{Dimensions of Spatial Party Competition in Montenegro, Serbia, and North Macedonia}

The ruling parties in the three competitive authoritarian regimes under study have positioned themselves as large-tent, centrist parties by absorbing crucial policy issues and strategically co-opting key actors into government. Authoritarian rulers shifted, deepened, or merged relevant programmatic dimensions, such as regime legacies, foreign policy, and national cleavages. In consequence, opposition parties repeatedly had to confront the changing dynamics of inter-party competition with different implications for the opposition's cohesion.

Legacies of predecessor regimes have a structuring effect on the formation of party systems. All three countries share a legacy of state socialism, while Montenegro and Serbia additionally experienced a period of autocratic rule in the 1990s.

Montenegro's ruling party, the Democratic Party of Socialists (DPS), is the successor of Montenegro's League of Communists. The DPS seamlessly retained power in the 1990s, as Montenegro formed a joint state with Serbia. In 1997, the party split from Milošević and transformed, led by Milo Đukanović, into a populist centre-left party endorsing a distinct Montenegrin identity and adopting a pro-Western policy. Its change of course aided the DPS to invite key actors from the aspiring proindependence and anti-Milošević opposition into government (Morrison 2009, 34). The DPS' co-optation divided Montenegro's civic opposition into regime-insiders and -outsiders. For example, Montenegro's leading pro-independence party at the time, the Liberal Party of Montenegro (LSCG), mainly maintained its anti-regime position. But when the DPS embarked on the cause of Montenegrin independence, the LSCG lost considerable support. The DPS' turnaround also gave rise to a substantial opposition faction that promoted a continued state federation with Serbia. Since Montenegro's independence in 2006, however, parties from the unionist camp have focused on identity issues. But their emphasis on Serb identity and close ties with Serbia has alienated civic opposition parties and their constituencies (Morrsion 2018, ch. 9). 
Serbia's ruling party, the SNS, broke away from the extreme right-wing Serb Radical Party (SRS) in 2008. During the 1990s, the SRS was an occasional junior partner of Milošević's Socialist Party of Serbia (SPS), the successor to the League of Communists. By 2003, the SPS re-gained relevance as the kingmaker in the competition between Serbia's largest reformist actors ${ }^{2}$ who had been united by little except their common opposition to the Milošević regime (Bochsler 2010). One consequence of the SPS' rehabilitation was that regime legacies forfeited their structuring property for inter-party competition. In 2008, the SNS emerged as an important party after a split within the SRS. The nominally pragmatic and reformist SNS managed to fill a void on the centre-right, left by the infighting among Serbia's reformist parties (Konitzer 2011). Chaired by Aleksandar Vučić, the SNS rose to power in 2012, whereupon Serbia's previously dominant parties fragmented along several dimensions. Crucial in this development was the disintegration of the Democratic Party of Serbia (DSS) and the split of the Democratic Party (DS) in multiple factions with the SNS co-opting a significant share of the party nomenclature (Bieber 2020, pp.44).

North Macedonia had no ruling authoritarian party in the 1990s. Between 1991 and 2006, North Macedonia's successor to the League of Communists, the centreleft Social Democratic Union of Macedonia (SDSM), and its counterpart, the anticommunist, nationalist Internal Macedonian Revolutionary Organisation-Democratic Party for Macedonian National Unity (VMRO-DPMNE) regularly alternated in government. During the eleven-year rule of the VMRO-DPMNE (2006-2017), the ruling party under the leadership of Nikola Gruevski became increasingly authoritarian, marginalising the opposition. In addition, all governments could rely on the support of the main Albanian minority party, the Democratic Union for Integration (DUI/BDI), that was part of governing coalitions between 2002 and 2020 (except 2006-2008). The SDSM persisted as the main opposition party and while losing votes, never faced serious fragmentation or challenges as has been the case in Serbia or Montenegro. The SDSM could rely on its large infrastructure and while it faced a serious decline in electoral support, it could dominate the opposition, mostly as the ruling party did not try to overcome the ideological divide and reach out to the political left (Šedo 2013).

Foreign policy objectives constitute the second dimension of party competition. Since 2000, Western Balkans' societies display a growing consensus on the positive implications of European integration. Anti-European parties were either politically marginalised or faced increasing pressure to reform, even if only superficially. This is reflected in the transformation of Montenegro's DPS in 1997 and North Macedonia's VMRO-DPMNE in 2003 (Šedo 2013). The SNS' founding in 2008 was equally an attempt of the SRS' pragmatic wing to escape domestic and international isolation caused by its anti-European stance. Similarly, anti-European positions have broadly vanished from the programmes of Western Balkans' opposition parties; the SRS and Dveri in Serbia or the Serb nationalist Democratic Front (DF) in Montenegro, two

\footnotetext{
2 SPS supported the DSS minority government, 2004-2007, and has been a coalition partner since 2008 (with DS 2008-2012, with SNS since 2012).
} 
countries in which pro-Russian and anti-NATO sentiments are high, mark the most prominent exceptions. In contrast to Montenegro, Serbia's opposition faces more difficulties to mobilise foreign policy issues against the regime. This is due to the fact that Serbia's dominant party managed to reconcile seemingly disparate foreign policy directions. Apart from a pro-European course, the SNS promotes close ties with China and maintains a strategic pro-Russian position, also expressed by its opposition towards NATO membership.

Finally, national cleavages continue to structure party interaction. The dominant parties in all three countries moderated their nationalist stances of the 1990s and attracted minority parties' support. Yet, these alliances are more grounded in the principle of 'divide and rule' rather than genuine concern for minority representation (see, for example, Bieber 2020, 55; Mús and Korzeniewska-Wiszniewska 2013). All three dominant parties continue to fuel nationalist sentiments. Examples include the VMRO-DPMNE's promotion of a Macedonian nation-building project (Ceka 2018), the ongoing subversion of a dialogue with Kosovo by Serbia's government-controlled media, or the creation of a distinct national identity by Montenegro's DPS. Thus, in trying to confront the ruling parties' dominant position, national issues present a potential for the opposition to divide. The most striking example is Montenegro, where the state-sponsored nation-building highlighted the differences between Serbs and Montenegrins, reinforcing political and social polarisation (Morrison 2018). However, the government's controversial Law on Religion in 2020, that the Serb Orthodox Church in Montenegro feared to lead to the expropriation of some of its churches, seemed to have overstepped a mark (RFE 2019). The law arose considerable outrage, tipping the scales towards the DPS' disadvantage in the 2020 general elections.

The comparison illlustrates that differently structured party systems promote different degrees of opposition cohesion and fragmentation. Opposition fragmentation is particularly pronounced in Serbia and Montenegro. Serbia's party system is characterised by various intersecting cleavages providing little ground for a broad antiregime alliance. This dynamic is reinforced by the fact that the SNS has absorbed a number of pivotal policy positions and, thus, has become a difficult target for a divided opposition. In Montenegro, the DPS reinforced the cleavage over Montenegro's state and nationhood and, in consequence, divided the opposition into civic and Serb nationalist parties. Central to this development in both countries was the fact that the dominant parties continuously co-opted parties and politicians from the opposition. In North Macedonia, the SDSM remained the main opposition party during the VMRO-DPMNE regime, competing en bloc with an established coalition of minor partners. The opposition's cohesiveness was not threatened by cross-cutting dimensions. But instead, the anti-Communist/ex-communist divide provided the SDSM with a clear distinction from the conservative/nationalist VMRO-DPMNE.

\section{Opposition Coalition Building}

Besides the main political cleavages, the ability of opposition parties to cooperate and form pre-election coalitions is a key determent of their success. The party systems of the Western Balkans are only weakly institutionalised, displaying a high 
level of volatility and unstable patterns of party interaction. The dominant parties in all three countries usually run for elections in pre-election coalitions with a large number of smaller parties of different ideological orientation. For example, the Serbian Progressive Party list for the 2016 parliamentary elections included nine parties, nominally representing a political spectrum stretching from far left to far right, mostly so small that they would not be able to enter parliament independently. They are also usually dominated by one politician linked to the regime through a ministerial post. In the case of the 2020 elections, the SNS' coalition partners were not even listed, but subsumed under the electoral list "Aleksandar Vučić, for our children". The link between the dominant party and the smaller parties mostly serves to increase the perception of political pluralism. Similarly, opposition coalitions often contain a large number of minor parties. For example, in the 2016 North Macedonian elections, the SDSM, the main opposition party, competed in coalition with thirteen other parties, including five minority parties.

Large parties, both from the regime and the opposition, form coalitions either to secure support from small, but well-defined electorates, such as national minorities, or parties with a specific local or demographic profile, to project the semblance of a broad coalition. As noted earlier, these pre-electoral coalitions are usually not grounded in a common programme. Rather, they are driven by the aim to pool votes, enabling smaller parties to pass the parliamentary threshold, which they would not be able to do on their own. This is also reflected in the fact that many of these coalitions disintegrate once they have entered parliament. In Montenegro and Serbia, preelection coalitions are closely tied to the high level of party system fragmentation, less so in North Macedonia. Pre-electoral coalitions reduce the costs of party splits as they allow even parties without sufficient independent electoral support to enter parliament. In turn, the frequent party splits, especially among opposition parties reinforce this practice.

In the Montenegrin parliamentary elections of 2016, sixteen parties and coalitions ran for elections against the DPS. The largest opposition groups included the Democratic Front (DF), composed of the New Serb Democracy (NOVA), the Movement for Changes (PzP), the Democratic People's Party (DNP), and the Democratic Serb Party (DSS). The other main opposition coalition "Key" included the Democratic Alliance (DEMOS), the Socialist People's Party (SNP), and the United Reform Party (URA). In addition, the Social Democratic Party (SDP) and Democratic Montenegro (DCG) won seats in parliament. This pattern is also mirrored in Serbia. By the end of the mandate of the Serbian parliament elected in 2016, thirtytwo parties were represented in parliament, ten of which are part of the opposition.

High fragmentation also undermines the ability of opposition parties to form a coherent message against dominant parties. In addition, where intra-opposition polarisation is pronounced, common platforms are difficult to achieve. In North Macedonia, the country case with the lowest level of party system fragmentation, the opposition appeared as a unified camp headed by the largest opposition party; only a few smaller parties emerged as independent challengers. In Montenegro, party system fragmentation largely reflected the divide between pro-Serbian opposition parties, that often included anti-system positions, and civic opposition parties, that accepted the key premise of the political system, such as NATO membership 
and the Montenegrin nation and state. In 2020, it was three clearly identifiable opposition coalitions, each appealing to a distinct electorate, that ousted the DPS. Serbia, on the other hand, has neither seen a unified opposition camp, as in North Macedonia, nor the formation of alternative party blocs which, although competing separately, share the goal of overthrowing the incumbent.

\section{Opposition Party Strategies}

Finally, opposition parties must choose their strategies in challenging authoritarian incumbents, as conventional institutions within a democratic system such as election campaigning and parliamentary oversight, might often not be available. Incumbents use a variety of strategies to tilt the playing field to their favour. These comprise media control or the use of state resources for patronage, undermining citizens' ability to vote freely. Other techniques include the manipulation of voter lists and even organised voting (BiEPAG 2017). In addition, institutions are often undermined by the ruling party to prevent any possibility for a change of power. For example, in North Macedonia on Black Monday in December 2013, the police removed opposition MPs and the media from parliament after the opposition had boycotted a budget vote. Similarly, in Serbia, the opposition has been systematically silenced in parliament. For example in 2017 and 2018, MPs of the ruling party flooded parliament with meaningless amendments to the budget law to use up the time for parliamentary debate and prevent criticism from the opposition. Similar strategies have undermined the effectiveness and ability of opposition MPs to participate in parliamentary work. Therefore, opposition parties also tend to opt for extra-institutional strategies, in particular boycotts and protests.

A frequent strategy chosen by opposition parties are boycotts. We must distinguish between election and parliamentary boycotts. Parliamentary boycotts have been common, as they are temporary and reversible. Such boycotts occurred in North Macedonia between 2014 and 2016 after the aforementioned eviction of the opposition in 2013. In 2016, the Montenegrin opposition boycotted parliament over election irregularities, although some parties later returned to parliament (Tomovic 2017). Most of Serbia's opposition parties boycotted parliament in 2019, following weeks of street protests (Zivanovic 2019). Boycotts seek to deprive parliaments of their legitimacy and are usually combined with specific demands for either early elections or reforms. Often, this has led to international mediation, in particular by the EU.

Election boycotts are less common in the Western Balkans, especially among larger opposition parties. Meaningful opposition boycotts occurred in 1994 in Macedonian parliamentary elections, in 1997 in the Serbian national elections, in 2019 in Albanian local elections, and in the 2020 Serbian parliamentary elections. The strategy is high risk: First, it allows the ruling party to strengthen control over institutions. Second, it might deprive the opposition of financial resources and a forum for public engagement, no matter how flawed. Third, election boycotts challenge the opposition's cohesion as some parties might be tempted to break ranks and benefit from the boycott of others. Election boycotts only succeed when 
they sufficiently dent elections' legitimacy, either domestically or internationally. They are also a strategy when the opposition is weak and fears to be undermined by an electoral defeat, as had been the case in the 2020 Serbian elections.

The final, and most common, extra-institutional strategy is protests. Protests are a classic strategy of citizen mobilisation. The purpose is to highlight citizen support and galvanise supporters of the regime. Protests are not the exclusive domain of political parties. In fact, protests have often involved broader social movements that are able to motivate citizens' participation beyond opposition party electorates. There is an established pattern of protest movements in the Western Balkans. In Serbia, we find two important protest waves against the government of Aleksandar Vučić. The first took place in 2016 and 2017, organised by the civil movement Don't Let Belgrade D(r)own (Ne da(vi)mo Beograd), that defied against the Belgrade Waterfront building project and later turned into an opposition movement (Vasovic 2017). The second protest occurred in 2018/2020 under the banner 1 of 5 Million. It was triggered by the beating of the opposition politician Borko Stefanović and took place in the context of worsening media freedom and attacks against the opposition. In weekly protests, carrying on for more than a year, more than ten-thousand demonstrators protested regularly, led by a coalition of opposition parties (Cvetković 2020). Both protest movements eventually fizzled out without achieving their demands.

In North Macedonia, two protest waves preceded the end of the Gruevski government in 2016. The first wave took place in May 2015 following the release of wire taps by the opposition implicating the government in abuse of office. The protests, including a tent city in front of the government building, were met with counter-protests organised by the regime. An even larger protest wave emerged in 2016 under the name Colourful Revolution (sharena revolucija) after President Gjorgje Ivanov sought to grant amnesty to members of the ruling party entangled in corruption and abuse of office. The protestors threw colours on buildings and monuments associated with the regime's controversial building project Skopje 2014. The protest was officially non-partisan and mainly organised by the social movement protestiram. However, it was closely coordinated by the main opposition party, the SDSM (Pudar Draško et al. 2019).

Montenegro has witnessed similar waves of protests. Demonstrations against the government erupted in 2015, initially organised by the Democratic Front. But following police repression, the protests expanded to include regime opponents beyond party lines. Another wave was stipulated in 2019 after a businessman who fell out with the regime revealed incidents of bribery in the government. While the opposition supported the protests, these emerged mostly spontaneously over corruption allegations (Vasovic 2019). Montenegro's latest protests have been led by the Serbian Orthodox Church in 2019 and 2020 against a controversial new Law on Religion that the church fears might lead to expropriations (RFE 2019). Most opposition parties supported the protests.

These different strategies highlight the challenges of opposition parties in competitive authoritarian regimes. Election boycotts have been rare and usually did not threaten regime legitimacy. Boycotts of parliament are a more frequent strategy. Often, they have triggered international mediation, but altogether, they have failed to 
address the fundamental imbalance of power between incumbent and opposition, or expose the dysfunction of the countries' nominally democratic institutions.

The parliamentary boycott of the Macedonian and Montenegrin opposition did not improve electoral conditions or parliamentary oversight. Rather, it was protests that had an important effect in the pre-election context. While the 2019/20 protests in Montenegro failed to stop the adoption of the Law on Religion, they have been successful in that they paved the way to the victory of the opposition in August 2020. The sustained level of protest considerably contributed to the pre-electoral mobilisation of opposition votes, as it signalled the incumbent's weakness and loss of support. Once defeated, the ruling DPS conceded the outcome of the August 2020 elections. Equally, in North Macedonia, protests preceded the electoral defeat of the dominant VRMO-DPMNE in December 2016. The so-called 'Colourful Revolution' succeeded due to its scale, its rootedness in civil society, wide-spread dissatisfaction with the ruling party, as well as external support from the European Union. In Serbia, on the other hand, protests failed to galvanise equally broad support for social movements and political parties. The causes of the protests unfolded less mobilising potential than in Montenegro or North Macedonia. Thus, they were unable to signal a sufficiently wide-spread opposition to the dominant party, resulting in a limited effect on mobilising anti-regime votes.

\section{Conclusion}

This article has argued that the ability of opposition parties to challenge competitive authoritarian regimes in three cases of the Western Balkans depends on three key dimensions: (a) the cleavages in the political system and how these are utilised by the incumbents, (b) opposition party coalitions and cooperation, and (c) the use of extra-institutional strategies. The ability to challenge competitive authoritarian regimes often depends on triggers, such as the revelation of extensive abuse of office, election fraud, or unpopular policies. However, these triggers can only engender the decline of an autocratic incumbent, if the opposition is able to overcome the structural obstacles outlined above.

Moreover, strategic resources, such as access to the media, material goods, and the distribution of power at the subnational level also shape the ability of opposition parties to compete effectively.

As this brief discussion of Serbia, Montenegro and North Macedonia highlights, challenging authoritarian regimes is difficult due to state-controlled elections, deep-seated clientelism, limited media freedom, and the regimes' co-optation of a pro-European agenda. The dominant parties in all three countries position(ed) themselves as large-tent centre parties that systematically limit the scope for programmatic contestation. Montenegro and Serbia display a number of similarities; the opposition in both countries is highly fragmented, to a large degree by the regimes' strategic manipulation of existing cleavages. In Montenegro, the ruling DPS has occupied the pro-Western affirmation of Montenegrin statehood and national identity, whereas the opposition is fragmented into anti-regime parties and parties that reject the larger orientation of the state. In Serbia, the ruling SNS occupies a wide 
ideological spectrum from pro-EU centrist positions to radical nationalist pro-Russian stances, providing little space for the opposition to define their position beyond the rejection of the regime. In North Macedonia, on the other hand, the conservative/nationalist VMRO-DPMNE could not use or shift cleavages. Thus, the majority-minority and anti-Communist/ ex-Communist cleavage that had shaped Macedonian party politics since the early 1990 s persisted.

Montenegro and North Macedonia are particularly insightful for the study of successful challenges to competitive authoritarian regimes. In North Macedonia, opposition unity proved crucial in the overthrow of the VRMO-DPMNE. In Montenegro, rather surprisingly, the post-electoral unification of initially competing opposition camps led to the same result. Crucial in this development was that the opposition parties could put aside their deep divisions in the realm of foreign policy to form a common coalition. Second, both cases have witnessed large-scale pre-election protests that mobilised large numbers of citizens, highlighting the degree of social dissatisfaction with the regime. Finally, in both cases, the opposition was united in its challenge to state capture, authoritarian practice, and corruption. In North Macedonia, this was also combined with a strong support for European integration and a pro-Western orientation of the opposition.

Funding Open access funding provided by University of Graz.

Open Access This article is licensed under a Creative Commons Attribution 4.0 International License, which permits use, sharing, adaptation, distribution and reproduction in any medium or format, as long as you give appropriate credit to the original author(s) and the source, provide a link to the Creative Commons licence, and indicate if changes were made. The images or other third party material in this article are included in the article's Creative Commons licence, unless indicated otherwise in a credit line to the material. If material is not included in the article's Creative Commons licence and your intended use is not permitted by statutory regulation or exceeds the permitted use, you will need to obtain permission directly from the copyright holder. To view a copy of this licence, visit http://creativecommons.org/licen ses/by/4.0/.

\section{References}

Bhasin, T., and J. Gandhi. 2013. Timing and targeting of state repression in authoritarian elections. Electoral Studies 32(4): 620-631.

Bieber, F. 2014. Of Balkan apples, oranges, grandmothers and frogs. Comparative politics and the study of Southeastern Europe. In Southeast European studies in a globalizing world, ed. C. Promitzer, S. Gruber, and H. Heppner, 127-139. Münster: LIT Verlag.

Bieber, F. 2018. Patterns of competitive authoritarianism in the Western Balkans. East European Politics 34(3): 337-354.

Bieber, F. 2020. The rise of authoritarianism in the Western Balkans. Basingstoke: Palgrave.

Bieber, F. and M. Kmezić. 2015. Media freedom in the Western Balkans. Balkans in Europe Policy Advisory Group (BiEPAG). http://www.biepag.eu/wp-content/uploads/2016/10/BIEPAG-Media-Freed om-in-the-Western-Balkans.pdf.

BiEPAG. 2017. The crisis of democracy in the Western Balkans. An anatomy of stabilitocracy and the limits of EU democracy promotion. http://biepag.eu/wp-content/uploads/2019/03/TheCrisisofdemo cracy.pdf.

Bochsler, D. 2010. The party system of Serbia. In Party politics in the Western Balkans, ed. V. Stojarová and P. Emerson, 99-119. London, New York: Routledge. 
Bunce, V.J., and S.L. Wolchik. 2011. Defeating authoritarian leaders in postcommunist countries. New York: Cambridge University Press.

Ceka, B. 2018. Macedonia: a new beginning? Journal of Democracy 29(2): 143-157.

Cvetković, L. 2020. Koliko ljudi broji '1 od 5 miliona'. Radio Slobodna Evropa. https://www.slobodnaev ropa.org/a/bojkot-1-od-5-miliona/30405563.html. Accessed 29 Jan 2020.

Dolenec, D. 2013. Democratic institutions and authoritarian rule in Southeast Europe. Colchester: ECPR Press.

Gandhi, J., and E. Ong. 2019. Committed or conditional democrats? Opposition dynamics in electoral autocracies. American Journal of Political Science 63(4): 948-963.

Gandhi, J., and G. Buckles. 2016. Opposition unity and cooptation in hybrid regimes. In Paper presented at the annual midwest political science association conference, Chicago, USA.

Greene, K.F. 2010. The political economy of authoritarian single-party dominance. Comparative Political Studies 43(7): 807-834.

Helms, L. 2020. Introduction: the nature of political opposition in contemporary electoral democracies and autocracies. European Political Science, forthcoming.

Keil, S. 2018. The business of state capture and the rise of authoritarianism in Kosovo, Macedonia, Montenegro and Serbia. Southeastern Europe 42(1): 59-82.

Konitzer, A. 2011. Speaking European: conditionality, public attitudes and pro-European party rhetoric in the Western Balkans. Europe-Asia Studies 63(10): 1853-1888.

LaPorte, J. 2015. Hidden in plain sight: political opposition and hegemonic authoritarianism in Azerbaijan. Post Soviet Affairs 31(4): 339-366.

Levitsky, S., and L. Way. 2002. The rise of competitive authoritarianism. Journal of Democracy 13(2): 51-65.

Levitsky, S., and L. Way. 2020. The new competitive authoritarianism. Journal of Democracy 31(1): 51-65.

Magaloni, B. 2006. Voting for autocracy: hegemonic party survival and its demise in Mexico. Cambridge, New York: Cambridge University Press.

Morrison, K. 2018. Nationalism, identity and statehood in post-Yugoslav Montenegro. London, New York: Bloomsbury Academic.

Morrison, K. 2009. The political life of Milo Djukanović. Southeastern Europe Journal of Politics and Society 57(1): 25-54.

Muś, J., and M. Korzeniewska-Wiszniewska. 2013. Divide et impera principle. Minority oriented state policy in the Balkans. New Balkan Politics 13: 73-89.

Pudar Draško, G., I. Fiket, and J. Vasiljević. 2020. Big dreams and small steps: comparative perspectives on the social movement struggle for democracy in Serbia and North Macedonia. Southeast European and Black Sea Studies 20(1): 199-219.

RFE. 2019. Montenegro passes law on religious communities amid anger, protests. Radio Free Europe. https://www.rferl.org/a/montenegro-religious-law-serbian-orthodox-church-protest/30346778.html. Accessed 27 Dec 2019.

Schedler, A. 2002. Elections without democracy: the menu of manipulation. Journal of Democracy (13)2: 36-50.

Schedler, A. 2006. The logic of electoral authoritarianism. In Electoral authoritarianism: the dynamics of unfree competition, vol. 1, ed. A. Schedler, 1-21. Boulder: Lynne Rienner Publishers.

Šedo, J. 2013. The party system of Macedonia. In Party politics in the Western Balkans, ed. V. Stojarová and P. Emerson, 187-199. London, New York: Routledge.

Tomovic, D. 'Montenegro opposition's parliament boycott starty to fray', BalkanInsight. https://balka ninsight.com/2017/12/13/boycott-of-montenegrin-parliament-starts-to-fray-12-13-2017/. Accessed 13 Dec 2017.

Vachudova, M.A. 2019. EU enlargement and state capture in the Western Balkans. In The Europeanisation of the Western Balkans: a failure of EU conditionality?, ed. J. Džankić, S. Keil, and M. Kmezić, 63-85. Palgrave: Basingstoke.

Vachudova, M.A. 2005. Europe undivided: democracy, leverage, and integration after communism. Oxford: Oxford University Press.

Vasovic, A. 2019. Thousands march in Montenegro capital to demand president to resign. Reuters. https://de.reuters.com/article/us-montenegro-protests-idUSKCN1QX0OD. Accessed 16 Mar 2019.

Vasovic, A. 2017. Thousands protest against Serb government and flagship project. Reuters. https://www. reuters.com/article/us-serbia-protests-idUSKBN17R2L6. Accessed 25 Apr 2017. 
Way, L. 2012. The sources of authoritarian control after the cold war: East Africa and the former Soviet Union. Post-Soviet Affairs 28(4): 424-448.

Wright, J., and A. Escribà-Folch. 2011. Authoritarian institutions and regime survival: transitions to democracy and subsequent autocracy. British Journal of Political Science 42(02): 283-309.

Zivanovic, M. 2019. Serbia opposition MPs boycott parliament after fresh protests. BalkanInsight. https:// balkaninsight.com/2019/01/28/serbian-opposition-boycotted-parliament-session-01-28-2019/. Accessed 28 Jan 2019.

Publisher's Note Springer Nature remains neutral with regard to jurisdictional claims in published maps and institutional affiliations.

Claudia Laštro is a Ph.D. candidate in comparative politics at the Centre for Southeast European Studies at the University of Graz. Her research interests include the resilience of autocratic regimes, nationalism, and institutional change with a regional focus on Southeast Europe. She is presently completing an article on the impact of nation-building on opposition coordination in Montenegro to be published in Südosteuropa Jahrbücher.

Florian Bieber holds the Jean Monnet Chair on the Europeanization of Southeastern Europe and is Professor of Southeast European History and Politics at the University of Graz. His research focuses on the post-Yugoslav countries, questions of democratisation and nationalism. Recent publications include The Rise of Authoritarianism in the Western Balkans (Palgrave 2020) and Debating Nationalism (Bloomsbury 2020). 